\title{
Icons of the Old Regime: Challenging South African Public Memory Strategies in \#RhodesMustFall
}

\author{
Carolyne E. Holmes \\ (Bucknell University) \\ Melanie Loehwing \\ (Mississippi State University)
}

Students engaged in the spring 2015 protests on the University of Cape Town campus demanded the removal of the statue of Cecil John Rhodes, prompting renewed debate over the appropriate treatment of colonial and apartheid-era statuary in contemporary South African public spaces. While the students' protests were often dismissed in public discourse and media coverage as misguided or misinformed, this article situates them in the broader context of symbolic reparations central to the transition to multiracial democracy. We introduce the terms 'monologic commemoration' and 'multiplicative commemoration' to describe the two dominant phases of South African public memory initiatives during and after apartheid. Monologic commemoration promotes a singular historical narrative of national identity and heroic leadership, whereas multiplicative commemoration requires the representation of as many diverse experiences and viewpoints as possible. We examine the \#RhodesMustFall campaign as an eruption of discontent with both the monologic and multiplicative approaches, potentially signalling a new 'post-transitional' phase of South African public culture.

\section{Introduction}

On 9 March 2015, University of Cape Town (UCT) student Chumani Maxwele defaced the campus statue of Cecil John Rhodes with human excrement, garnering international attention for his challenge to the colonial icon. This singular defiant act spawned a wave of protests in which students and supporters demanded that the university administration remove the Rhodes statue as the first gesture toward unsettling the Eurocentric orientation of the university curriculum, faculty, and campus. As the protest gained momentum, the impulse to desecrate statues commemorating colonial and apartheid leaders spread to other South African cities, provoking heated debate across the country and around the world about the suitability of colonial-era statues in contemporary democratic nations. ${ }^{1}$ At UCT, the protesters organised around the hashtag-inspired campaign name '\#RhodesMustFall' and co-ordinated a series of sit-ins and demonstrations calling for the removal of the Rhodes statue and the 'decolonisation' of education in South Africa. ${ }^{2}$

Yet within the context of Cape Town, the image and name of Rhodes are still commemorated in myriad venues. Maylam notes Rhodes's lingering presence in the city in 2002, saying,

[o]ne can walk through the Cape Town Gardens and encounter a large statue of Rhodes, then heading towards the city center pass by the Rhodes Building. A walk down the main steps at UCT would bring one

1 A. Harding, 'Cecil Rhodes Monument: A Necessary Anger?' BBC News, London, 11 April 2015, available at http://www.bbc.co.uk/news/world-africa-32248605, retrieved 19 October 2016.

2 Y. Kamaldien, 'Rhodes Statue: Students Occupy Offices', IOL News, 21 March 2015, available at http://www.iol.co.za/news/south-africa/western-cape/rhodes-statue-students-occupy-offices-1835276, retrieved 19 October 2016. 
to another statue of Rhodes. Then one could drive along Rhodes Avenue before taking a turn-off up to the Rhodes Memorial. ${ }^{3}$

These commemorations of Rhodes seem to be part of a self-styled campaign to ensure a legacy, and focus on the intellectual, masculine and heroic virtues of their subject. ${ }^{4}$ The protest against one particular image of Rhodes was not a call for the total eradication of the image or legacy of the man himself, but rather a targeted critique of one particular depiction of Rhodes within the context of a postcolonial university.

The \#RhodesMustFall protests have succeeded at least in accomplishing their most explicit objective. On 9 April 2015, the statue of Rhodes was removed from the centre of UCT's campus, and the university community continues to engage in discussions about how to address its on-going racial inequalities and conflicts. ${ }^{5}$ The dissemination of the \#RhodesMustFall protest frames, social media tactics and approach has also been dramatic, with student-led movements arising around the country, articulating concerns over the language media of education ${ }^{6}$ and the price of higher education, ${ }^{7}$ and connecting student struggles to the protests of mineworkers in Marikana $^{8}$ and the struggle for land redistribution. ${ }^{9}$

Yet the protests' reception has been far from unanimously favourable. Typical critiques of the movement's efforts include assertions that the protesters were more concerned with frivolous symbols instead of pressing, real-world problems; that they demonstrated a lack of reverence for the multicultural ethos of the Rainbow Nation; and that their actions were immature and attention-seeking. ${ }^{10}$ Writing in the London Guardian, UCT alumnus Siya Mnyanda voiced a common charge by recognising the 'dubious past' of Rhodes while simultaneously rejecting the \#RhodesMustFall objectives: 'I think Rhodes should be left exactly where he is. Removing him omits an essential part of the institution's history that has contributed to everything good, bad and ugly about it - and arguably the country too'. ${ }^{11}$ Indeed, charges that the protesters wanted to rewrite history rather than grapple with its most difficult legacies dominated the opposition and inspired counter-protests devoted to protecting the statues commemorating British and Afrikaans figures. In this way, public opposition to the \#RhodesMustFall campaign and its affiliated protests has interpreted the students' arguments as

3 P. Maylam, 'Monuments, Memorials and the Mystique of Empire: The Immortalisation of Cecil Rhodes in the Twentieth Century', African Sociological Review 6, 1 (2002), p. 141.

4 E.A. Mare, 'Monumental Complexity: Searching for the Meaning of a Selection of South African Monuments', South African Journal of Art History, 22, 2 (2007), pp. 36-48.

5 D. Neille and R.L. Brown, 'After Fall of Statue, South African University Weighs Colonial Legacy', Christian Science Monitor, 9 April 2015, available at http://www.csmonitor.com/World/Africa/2015/0409/After-fall-of-statueSouth-African-university-weighs-colonial-legacy-video, retrieved 19 October 2016.

6 M. Shabangu, 'Not Open, Says Open Stellenbosch', Mail \& Guardian, 28 August 2015, available at http://mg.co.za/article/2015-08-27-not-open-says-open-stellenbosch, retrieved 19 October 2016.

7 B. Nkosi, 'Student Protest Brings Wits University to a Standstill', Mail \& Guardian, 14 October 2015, available at http://mg.co.za/article/2015-10-14-student-protest-brings-wits-university-to-a-standstill, retrieved 19 October 2016.

8 'UCT Rhodes Must Fall Mission Statement', The Salon, volume 9, available at

http://jwtc.org.za/resources/docs/salon-volume-9/RMF Combined.pdf, retrieved 19 October 2016.

9 Ibid.

10 For a relatively comprehensive summary of the main points of contention in the Rhodes statue controversy, see Groundup Staff, 'The Process', Mail and Guardian, 14 May 2015, available at http://mg.co.za/article/2015-05-14uct-and-transformation-part-one, retrieved 19 October 2016.

11 S. Myanda, 'Cecil Rhodes' Colonial Legacy Must Fall - Not His Statue', Guardian, London 25 March 2015, available at https:/www.theguardian.com/world/2015/mar/25/south-africa-rhodesmustfall-statue, retrieved 19 October 2016. 
a rejection of the commemorative artefacts of the colonial and apartheid era and an attempt to erase them both from public space and from public memory.

Despite these common criticisms of the \#RhodesMustFall participants, we contend that the emergence of these protests should be understood as co-ordinated political resistance to the core commemorative strategies embraced by the South African nation since the early 20 th century, and the failure of those strategies to produce the multiracial national harmony promised by the symbolic reparations of the negotiated transition. In an interview with National Public Radio (NPR), \#RhodesMustFall student leader Kgotsi Chikane situated the protest as a timely response to on-going political and economic disparities:

this is happening now because South Africa is coming out of its infancy years and into the teenage years of questioning everything. We're not taking the words of Nelson Mandela at face value. The idea that the 1994 political and economic compromise worked out best for all South Africans, we should be able to question that. I'm not talking about civil war and revolution, but to have young people's voices heard, for people to start questioning. ${ }^{12}$

It is no coincidence that a public monument became the site for expressing the dissatisfaction with the negotiated transition because, as we argue in this essay, the political trade-off of the core commemorative strategy adopted by the post-apartheid government was a kind of diversity without conversation - or, in the students' words, compromise without question. Public memory in South Africa has consistently been constructed through commemorative sites and structures that strategically re-present the past, construct common identities for the present, and anticipate particular visions of shared political futures. Contextualised in this history of public commemoration as nation-building, the \#RhodesMustFall protests appear not as the frivolities of individual sensitivity but as a critical backlash against previous strategies of commemoration. Specifically, we see the \#RhodesMustFall protests as an eruption of the dissatisfaction with the governmental policy immediately following the transition to democracy of leaving colonial and apartheid-era monuments intact.

Examined as an isolated incident, the \#RhodesMustFall protests appear to public critics as an attempt to excise an objectionable public figure from the historical record. But we contend that the \#RhodesMustFall protests must be understood in the context of a broader trajectory of national commemorative strategies spanning the periods of colonialism, apartheid, and the transition to multiracial democracy. We propose two categories for making sense of the major approaches to South African public memory: monologic and multiplicative commemoration. During colonial and apartheid rule, monologic commemoration was utilised to identify and celebrate heroes and leaders in order to construct a singular vision for the South African nation. After the negotiated transition that ended apartheid, multiplicative commemoration was embraced by the new, democratic government as a remedy that might facilitate the expression and validation of multiple voices and points of view. While monologic and multiplicative approaches are not mutually exclusive, distinguishing between them helps us to understand how various commemorative strategies may serve different strategic political ends, and we illustrate each commemorative approach with representative monuments in order to delineate their key defining features. We then examine the \#RhodesMustFall protests as symptomatic of the

12 K. Chikane, interviewed in D. Boroughs, 'Why South African Students Say the Statue of Rhodes Must Fall' (emphasis added), NPR, 28 March 2015, available at

http:/www.npr.org/sections/goatsandsoda/2015/03/28/395608605/why-south-african-students-say-the-statue-ofrhodes-must-fall, retrieved 19 October 2016. 
discontent produced by the lingering artefacts of monologic commemoration and the pursuit of a non-dialogic - and therefore relatively uncritical - multiplicative strategy. We conclude by considering the implications of the \#RhodesMustFall campaign for the on-going negotiation of public memory in a democratic culture.

\section{South African Public Memory}

For public memory scholars, commemorative sites and structures operate as an important site for the construction and revision of national identity. In South Africa, the negotiation of national identity at key points of political transition has often proceeded through the erection of statues, monuments, memorials, and museums that re-interpret the shared history of the nation and instruct the public on how to imagine their place in the present moment. ${ }^{13}$

In general, extant scholarship on South African public memory and visual culture is organised around a number of common themes: first, commemoration of suffering during apartheid and the rise of resistance to it honours the central role that art played in providing an arena in which political opposition could be voiced. ${ }^{14}$ South African memorials and monuments are engaged in a process of negotiating collective or public memory as a means of articulating the national identity of the new South Africa. ${ }^{15}$ These sites typically do so by providing a public platform that empowers and highlights previously excluded or de-legitimised voices, thereby offering a diversity in representation that more closely mirrors the diversity of South African culture. ${ }^{16}$ While a primary objective of many memorials is to foster unity after an era of divisive conflict, ${ }^{17}$ others strategically attempt to resist reassuring or comforting the public. ${ }^{18}$ In the light of the wide range of commemorative strategies and the varying uses to which singular monuments are put, South African memorials provide a particularly apt illustration of the polysemous nature of public memory.

While previous studies of South African public memory have often investigated singular sites or monumental architecture in depth, this article engages a wider range of important sites of colonial, apartheid and post-apartheid public memory to discern broad commemorative trends. We illustrate the concepts of monologic and multiplicative commemoration by examining significant, large-scale memorials such as the Voortrekker monument, Robben Island, the Language monument and the Apartheid museum in order to understand the interplay between monuments erected by and for the cause of minority government, as well as those that valorise the struggle for multiracial democracy. These structures exist within the same general contexts and often portray vastly different kinds of historical narratives, and yet are often examined in relative isolation, rather than as potentially interacting components of a national commemorative landscape.

13 A.E. Coombes, History After Apartheid: Visual Culture and Public Memory in a Democratic South Africa (Durham, Duke University Press, 2004); S. Marschall, Landscape of Memory: Commemorative Monuments, Memorials, and Public Statuary in Post-Apartheid South Africa (Leiden, Brill, 2010).

14 J. Peffer, Art and the End of Apartheid (Minneapolis, University of Minnesota Press, 2009).

15 K.A. Bakker and L. Muller, 'Intangible Heritage and Community Identity in Post-Apartheid South Africa', Museum International, 62 (2010), pp. 48-56.

16 S. Marschall, 'Gestures of Compensation: Post-Apartheid Monuments and Memorials', Transformation: Critical Perspectives on Southern Africa, 55 (2004), pp. 78-95.

17 C. Teeger and V. Vinitzky-Seroussi, 'Controlling for Consensus: Commemorating Apartheid in South Africa', Symbolic Interaction, 30 (2007), pp. 57-78.

18 E. Rankin, 'Creating/Curating Cultural Capital: Monuments and Museums for Post-Apartheid South Africa', Humanities, 2 (2013), pp. 78-98. 
In surveying some of the most significant sites of commemoration from all of these periods, we aim to understand the environment that inspired both the \#RhodesMustFall protests and the backlash against them. The protests at UCT, although focused on the particular memorialised object of Rhodes, were a response to a larger environment of memorialisation. To understand this makes it easier to understand why the protests (and counter-protests) spread relatively quickly throughout the country. By surveying the strategies of memorialisation, especially the move from monologic to multiplicative commemoration associated with the transition to multiracial democracy, the students' critique may be placed in a national context.

Engaging a diverse range of public memory sites and structures, we use the language of 'commemoration' to describe the multi-faceted memory work being done in both construction and critique: the construction of statues, memorials, and museums, and the critique of the fittingness of specific historical narratives and values embodied by such artefacts. A family of terms has come to describe the types of public memory products and processes that we categorise under the headings of monologic and multiplicative commemoration in this essay. Among these, 'monument' and 'memorial' have received the most sustained scholarly attention as analyses attempt to establish clear distinctions between the two. ${ }^{19}$ Typically, monuments glorify their subjects, extolling their virtues and victories; theirs is a celebratory rhetoric of triumph over past obstacles. Memorials tend towards a more sober tone, marking the deaths of individuals or past losses in order to enable reconciliation and healing. ${ }^{20}$ Our purpose here is not to suggest that these categories of 'monument' and 'memorial' are static or mutually exclusive, nor do we adhere to rigidly technical definitions of the terms. Instead, we work within the language of 'commemoration' in order to engage the broad-reaching rhetorical process that builds a national present on the valorisation of past struggles and achievements. ${ }^{21}$

\section{Monologic Commemoration}

The various stages of the memorialisation of colonial and apartheid leaders that took place between the creation of the Union of South Africa in 1910 and the demise of apartheid specifically, and minority-controlled government in general, had a common project. Whether attributable to the Calvinist sense of divine election that animates much of the Afrikaans and apartheid mythos ${ }^{22}$ or the Enlightenment-inspired missionary and military zeal of the British colonial project, ${ }^{23}$ the central narrative theme of much of the monumental architecture of colonial and apartheid South Africa was to justify the perpetration of minority rule. This assertion is not meant to imply that these projects were united or mutually reinforcing, however. A key difference is that the monuments erected in the cause of Afrikaner nationalism and the apartheid project generally stress the nativity of Afrikaners in South Africa, ${ }^{24}$ while the same claims do not

19 S. Marschall, 'Visualizing Memories: The Hector Pieterson Memorial in Soweto', Visual Anthropology, 19,2 (2006), pp. 145-69; S. Marschall, 'Transforming the Landscape of Memory: The South African Commemorative Effort in International Perspective', South African Historical Journal, 55, 1 (2006), pp. 165-85.

20 A. Danto, The State of the Art (New York, Prentice Hall, 1987).

21 K. Savage, Standing Soldiers, Kneeling Slaves: Race, War, and Monument in Nineteenth-Century America (Princeton, Princeton University Press, 1997).

22 M. Vestergaard, 'Who's Got the Map? The Negotiation of Afrikaner Identities in Post-Apartheid South Africa', Daedalus, 130, 1 (January 2001), pp. 19-44.

23 J.S. Galbraith, Crown and Charter: The Early Years of the British South Africa Company (Berkeley, University of California Press, 1974).

24 J. Beningfield, 'Native Lands: Language, Nation and Landscape in the Taal Monument, Paarl, South Africa', Social Identities, 10, 4 (July 2004), pp. 509-25; A.E. Coombes, 'Translating the Past: Apartheid Monuments in 
seem to be inherent in the design or self-presentation of British monuments. Yet both seek to ground the project of minority rule in the geographic space of South Africa, with an eye to its perpetuation into an unseen future.

Tracing this broad history in South Africa reveals that early memorialisation strategies constructions of monuments to early colonial and apartheid leaders - use a common approach, which we are calling 'monologic commemoration'. Monologic commemoration occurs in the form of public monuments, specifically statues, engaged in a type of non-reflexive representational practice that aims transparently to produce icons, or re-presentations of historical figures.

Monologic commemoration aims to achieve three key objectives: to extol the greatness of the leaders of the apartheid and colonial governments; to legitimate white rule and ground it in the space of southern Africa; and to assert a singular vision of the nation, as led by these great, white men. ${ }^{25}$ In this, the colonial and apartheid governments participated in a commemorative project not wholly unlike other such projects on the continent, which emphasise the fixity and homogeneity of their subjects. ${ }^{26}$

\section{Extolling Great Men}

In exalting the particular figures of individual men, monologic commemorations celebrate the power and might of the minority rulers, and celebrate the 'civilising mission' undertaken on the continent in the name of religion, empire and race. Perhaps most prolific among the figures celebrated, and certainly most relevant for the subject at hand, is the (auto)hagiography of Cecil John Rhodes throughout southern Africa. Similar monuments in Zimbabwe have been used as evidence that Rhodes himself sought to establish a 'ruler cult' through connections between the natural landscape, the memory of the ruler, and the meaning of the nation. ${ }^{27}$

As referenced in the introduction, the presence of Rhodes throughout Cape Town is inescapable, in no small part because of the large memorial to him that is placed to overlook the city from the slope of Devil's Peak. As Keath and Baker explain, the monument - constructed in an Egyptian style and prominently featuring sphinx figures - was meant by the architect to invoke the Africanness of the subject of remembrance. ${ }^{28}$ The memorial, erected and commemorated in 1908, includes a statue depicting Rhodes in a meditative mode, accompanied by a quote from Rudyard Kipling, which says, '[t]he immense and brooding spirit still shall order and control. Living he was the land, and dead his soul shall be her soul'. ${ }^{29}$ In this inscription, Rhodes, the deceased man, is transmuted into the very essence of the land, in addition to serving

Post-Apartheid South Africa', in A. Brah and A. Coombes (eds), Hybridity and Its Discontents: Politics, Science, Culture (New York, Routledge, 2005), pp. 173-97.

25 A. Crampton, 'The Voortrekker Monument, the Birth of Apartheid, and Beyond', Political Geography, 20,2 (February 2001), pp. 221-46; P. Maylam, The Cult of Rhodes: Remembering an Imperialist in Africa (Claremont, New Africa Books, 2005).

26 D.R. Peterson, 'Introduction: Heritage Management in Colonial and Contemporary Africa', in D.R. Peterson, K. Gavua and C. Rassool (eds), The Politics of Heritage in Africa: Economies, Histories, and Infrastructures (New York, Cambridge University Press, 2015), pp. 1-36.

27 D. Lowry, “The Granite of the Ancient North": Race, Nation and Empire at Cecil Rhodes's Mountain Mausoleum and Rhodes House, Oxford', in R. Wrigley and M. Craske (eds), Pantheons: Transformations of a Monumental Idea (Burlington, Ashgate Press, 2005), pp. 193-220.

28 M. Keath, Herbert Baker: Architecture and Idealism, 1892-1913 : The South African Years (Gibraltar, Ashanti Publishing, 1992), p. 130.

29 D. Chidester, 'Mapping the Sacred in the Mother City: Religion and Urban Space in Cape Town, South Africa', Journal for the Study of Religion, 13, 1-2 (2000), pp. 5-41. 
as its civiliser during his life. These memorials, by placing Rhodes as a central figure of civilisation, as well as a man intentionally in, but not of, Africa, seek to place and legitimate their subjects within the context of southern Africa, and South Africa specifically.

Yet the deeds and figures of individuals have also been celebrated within the context of memorial sites erected by and for Afrikaner nationalists. The Voortrekker Monument, just outside Pretoria, prominently features the images and deeds of individual participants in the Great Trek, such as Piet Retief, Andries Pretorius, and Hendrik Potgieter, who symbolically guard the monument itself in the four cardinal directions. The interior of the monument showcases friezes that depict the conflict between Afrikaner boere (farmers) who had migrated from the Cape Colony to escape British colonial rule and the Zulu izimpi (armies) who held the land on which the trekkers sought to settle. ${ }^{30}$ The final frieze, which was envisaged as the culmination of the Voortrekker story and as a depiction of the divine election of Afrikaners in South Africa, portrays the building of a church in the vicinity of contemporary Pietermaritzburg. The architect, Gerard Moerdijk, again drawing prominently on Egyptian inspiration, intended the monument to stand as a symbol of these great deeds, and of the variety of symbols and manifestations of Afrikaner power ( $k r a g)$ and divine election (aanwysing) for 'a thousand years or more'. 31

\section{Legitimating White Rule}

Perhaps the most significant undertaking of the monologic commemoration project was to legitimate and ground white minority rule within the context of South Africa. For monuments erected by both the apartheid and colonial governments, this stance largely took the form of portraying the civilising mission of the colonists, but also for the apartheid government, often tied to assertions of indigeneity and nativity. The celebrations of Rhodes and the Voortrekkers in the monuments discussed above specifically reference the importance of the civilising mission as a legitimating rationale for commemoration and presence.

Included in the monumental design of the Voortrekker Monument is an eternal flame, which was lit in the laying of the first stones of the monument by a flame carried in a reenactment of the Great Trek from Cape Town to Pretoria. The flame was selected to symbolise the light of civilisation carried with the Afrikaners from the Cape Colony into the interior of the

country. ${ }^{32}$ By celebrating this election by God, and by linking the symbols of power to the places and environment of the southern tip of Africa, the monumental architecture claims not only the historical fact of military victory in 1838, but also the rightness of the cause and the presence of Afrikaners.

The Women's Monument (Vroemonument) was inaugurated in 1913 to commemorate the white women and children who were put into concentration camps during the Anglo-Boer war. This monument stands outside Bloemfontein, and comprises an obelisk with two attendant inscriptions on either side. On one side, the inscription reads, 'For Freedom, Volk and

30 M. Leslie, 'Bitter Monuments: Afrikaners and the New South Africa', The Black Scholar, 24, 3 (July 1994), pp. 33-9.

31 I. Vermeulen, Man en monument: die lewe en werk van Gerard Moerdijk (Pretoria, J.L. van Schaik, 1999), p. 129. See also A.M. Grundlingh, 'A Cultural Conundrum? Old Monuments and New Regimes: The Voortrekker Monument as Symbol of Afrikaner Power in a Postapartheid South Africa', Radical History Review, 81, 1 (2001), pp. $95-112$.

32 E. Delmont, 'The Voortrekker Monument: Monolith to Myth', South African Historical Journal, 29, 1

(November 1993), pp. 98-9. 
Fatherland', ${ }^{33}$ while the other says, 'I shall not forsake/fail you, I shall not leave you'. ${ }^{34}$ These inscriptions, which are paired with statues depicting stoically suffering volksmoeder/mother of the nation archetypes, ${ }^{35}$ seem to claim that, although militarily defeated, the Afrikaner volk are tied to South Africa both as a fatherland and through the suffering of their women and children. Though interpreted by some scholars as an eliding of the emasculation of military defeat and a re-focusing on women as objects of pity, ${ }^{36}$ this monument is perhaps the most deeply confrontational within the white community of minority rulers in South Africa, directly commemorating the armed conflict between Afrikaner and British forces. What it seeks to establish, however, is the moral injustice of the concentration camps as well as the deep ties between the volk and the land. ${ }^{37}$ By telling this version of the war narrative, the monument grants rightful claim to the land by virtue of suffering and sacrifice.

\section{Asserting a Singular Vision of the Nation}

Central also to the project of monologic commemoration is the assertion of the unity and cohesion of the nation. The unity pursued by monologic commemoration was unity for the white population, and for post-Anglo-Boer War reconstruction. ${ }^{38}$ In building a cohesive nation, the monologic commemoration strategy sought to undercut dissent and assert a sense of history and identity to a formerly divided community after the Unification of 1910 . The construction of a singular vision affords monologic commemoration the opportunity to imply an inevitability to the white rule it legitimates, implicitly discouraging alternative historical narratives or experiences that might suggest a diverse population that may equally lay claim to shared political governance, inclusion, and empowerment.

Inaugurated in 1975, the Afrikaans Language Monument (Taalmonument) in Paarl commemorates the 50th anniversary of the official separation of Afrikaans and Dutch languages and the centenary of the founding of the Genootskap van Regte Afrikaners (Society of Right/True Afrikaners). ${ }^{39}$ In commemorating language, this monument also celebrates the Africanness of the language, its distinction from Dutch and the origins of the language in the Cape. ${ }^{40}$ The monument itself contains an inscription from Afrikaans poet and scholar N.P. van Wyk Louw, which reads, '[b]ut we must never forget that this change in land/country and in landscape honed, kneaded and knit together this new and varied language ... and so Afrikaans was able to speak out from this new land/country'. ${ }^{41}$ The unity asserted by the monument builds

33 Original text: 'Voor Vryheid, Volk en Vaderland'.

34 Original text: 'Ik Zal u Niet Begeven, Ik Zal U Niet Verlaten'. See E. Cloete, 'Writing Of(f) the Women of the National Women's Monument', Literator, 20, 3 (1999), pp. 35-50.

35 E. Cloete, 'Afrikaner Identity: Culture, Tradition and Gender', Agenda, 8, 13 (1992), pp. $42-56$.

36 See, for example, A. McClintock, "No Longer in a Future Heaven": Women and Nationalism in South Africa', Transition, 51 (1991), pp. 104-23.

37 Both volk and land are Afrikaans words that notoriously defy translation into English. Volk, akin to its German and Dutch manifestations, means simultaneously people and nation, with strong affective, descent-based and emotional ties. Land, which means both country and land, has a strong nationalist history in Afrikaans and is very evocative of senses of belonging and space.

38 A. Marx, Making Race and Nation: A Comparison of South Africa, the United States and Brazil (New York, Cambridge University Press, 1998).

39 S. Smith, 'Monumentalising Language: Visitor Experience and Meaning Making at the Afrikaanse

Taalmonument', PhD thesis, Southern Cross University, New South Wales, Australia, 2013, available at http://epubs.scu.edu.au/cgi/viewcontent.cgi?article=1351\&context=theses, retrieved 17 October 2016. 40 Beningfield, 'Native Lands'.

41 Original Afrikaans: 'Maar wat ons nooit moet vergeet nie, is dat hierdie verandering van land en landskap as't ware aan die nuwe wordende taal geslyp, geknee, gebrei het ... En so het Afrikaans in staat geword om hierdie 
both on the claims to nativity and the distinction of Afrikaner identity from its European predecessors. In the context of compulsory education in Afrikaans, which was mandated in the year following the dedication of the monument, to speak a distinctly South African language thereby affirmed both place and unity.

In a variety of ways, all of the monuments discussed above assert a vision of a community, rooted in place and led by powerful and effective men, which elides dissent or competing visions. The friezes of the Voortrekker Monument do not allow for anything other than the teleology of history resulting from divine election. The light of civilisation from the Rhodes Memorial assumes not only a sympathetic viewer, but, again, a sacred trust that is unimpeachable. The codification of language and the separation of Afrikaans from Dutch is another kind of claim of unity for speakers of the language, as well as a distinction from the European context. Even the Women's Monument, which highlights the suffering of the women and children in the concentration camps, emphasises the unity and importance of the suffering of white civilian victims of the war. ${ }^{42}$

\section{Implications of the Monologic Model}

From these examples, we can start to glean the generic features of the monologic model. We identify monologic commemoration in the South African context as a strategy that seeks to create the impression of a uniform history and identity for the national community, a sense of the legitimacy and indigeneity of white rule, and the particular figures of great men. Such monuments typically do so by presenting the public audience with a vision of the past as one filled with triumphs worthy of preservation and emulation. Moreover, the monologic model asserts an essential continuity between the singular voice preserved in its monuments and the anticipated future for the community sharing its political vision. Monologic memorials emphasise the glories of heroic actions and the march of progress, casting their central characters as indisputable protagonists in the historical lead-up to the present moment.

Yet, as history has made clear, the ideology and practice of minority rule was defeated in South Africa. The aspirations of the apartheid and colonial governments have been deemed illegitimate, as have the implications of the memorials they have erected. So why, then, do so many artefacts of these commemorative strategies still exist in South Africa? As will be discussed below, the persistence of such monuments in the post-apartheid period was the result of a strategy of multiplicative commemoration, which aimed to destabilise and thereby reconcile the monumental landscape of the newly formed, inclusive, democratic public sphere.

\section{Multiplicative Commemoration}

Despite differences in the particulars of their substance and style, South African memorial attempts after the transition to democracy overwhelmingly employed an orientation that we are calling 'multiplicative commemoration'. What this means in practice, for example, is that the statue of Rhodes in the middle campus of the University of Cape Town was not removed, but instead was joined by commemorative objects made by, for and about the black African and Khoisan presence in the Cape Town area. In addition to the Rhodes statue, art pieces and memorials have been placed around the campus since the 1980s that are symbols of resistance to

nuwe land uit te sê'; our translation. See C. van der Rheede, 'Die Pad van Die Stigting Vir Bemagtiging Deur Afrikaans', Litnet, 22 September 2011, available at http://www.litnet.co.za/Article/die-pad-van-die-stigting-virbemagtiging-deur-afrikaans, retrieved 19 October 2016.

42 L. Stanley, Mourning Becomes ... 
apartheid, such as the Academic Freedom Wall in middle campus, as well as in commemoration of the Khoisan and Xhosa heritage in the sculptures entitled Kava va nga heti and Hoerikwaggo in the upper section of the campus, relatively close to the Rhodes plinth. ${ }^{43}$ Marschall explains the unique and urgent proliferation of memorials dedicated to anti-apartheid struggle heroes as a necessary response to 'the post-apartheid government's policy to leave the existing record of colonial and apartheid-era monuments largely untouched' ${ }^{4}$

Unlike their monologic predecessors, these multiplicative approaches do not seek to create a fictitious national unanimity, but instead pursue a polyvocal representation of various components of the national community. The post-apartheid policy of preserving colonial and apartheid monuments, while populating the landscape with newly commissioned memorials to the suffering and heroic resistance of black South Africans, encouraged the diversification of the symbolic landscape. ${ }^{45}$ By engaging in multiplicative commemoration, these memory sites and products participate in the aggregation of diverse representations and perspectives that appear alongside each other but do not necessarily interact with one another.

Since 1994, these memorials have also served a central function in constructing a shared history and identity for the post-apartheid South African nation. ${ }^{46}$ In this way, multiplicative commemorations are as much about the present as they are about the past. ${ }^{47}$ Such monuments participate in the effort to generate a public memory of pre-democratic South Africa exemplified by the Truth and Reconciliation Commission hearings. ${ }^{48}$ Through articulating these shared histories, memorials aim to create unity out of conflict, equality out of inequality, by inventing new national identities that transcend the divisions characterising the earlier era. The postapartheid monuments that appear with increasing frequency aim to create a counterbalance in what would otherwise be a monologic - and therefore univocal and exclusionary - representation of the nation's past by commemorating struggle heroes alongside the statues and monuments of the earlier era of oppression. Multiplicative commemoration pursues this inclusive goal through the preservation of individual experiences of apartheid, the re-interpretation of historical narratives to serve democratic norms, and the legitimation of previously marginalised voices.

\section{Preserving Individual Experiences}

Multiplicative commemoration resists the univocality of the monologic approach by prioritising the diversity of individual experiences of and reactions to apartheid. Selecting single public figures to stand in for the population as a whole would only substitute one (post-1994) monologic vision of the South African nation for the earlier one; instead, multiplicative commemoration after the transition to democracy prioritises and facilitates the polyvocal expression of many divergent perspectives on life under apartheid rule. Emblematic of this diversity is the Apartheid Museum, which opened in 2001 in Johannesburg in order to document

\footnotetext{
43 See 'Heritage@UCT', n.d., available at https://www.uct.ac.za/downloads/uct.ac.za/about/introducing/heritage/heritagetrail.pdf, retrieved 19 October 2016. 44 S. Marschall, 'Commemorating "Struggle Heroes": Constructing a Genealogy for the New South Africa', International Journal of Heritage Studies, 12, 2 (2006), p. 177.

45 A.K. Hlongwane, 'Commemoration, Memory and Monuments in the Contested Language of Black Liberation: The South African Experience', Journal of Pan African Studies, 2, 4 (2008), pp. 135-70.

46 A.E. Coombes, History After Apartheid: Visual Culture and Public Memory in a Democratic South Africa (Durham, Duke University Press, 2003).

47 S.H. Browne, 'Remembering Crispus Attucks: Race, Rhetoric, and the Politics of Commemoration', Quarterly Journal of Speech, 85 (1999), pp. 169-87. 48 Marschall, 'Commemorating "Struggle Heroes"'.
} 
the variety of South Africans' experiences under apartheid and the popular resistance that arose to challenge it. ${ }^{49}$

Unlike monologic commemorations that strive for simplicity, the Apartheid Museum archives the documentary footage and photographs, testimonies, and artefacts illustrating personal narratives and official polices of apartheid rule. Elizabeth Rankin and Leoni Schmidt make sense of the museum's rhetorical production of complexity in terms of 'empathetic unsettledness', or the strategic creation of 'an experience which is deeply infused with a lack of clarity'. ${ }^{50}$ They examine the museum as a commemorative structure whose symbolic power lies more with the experience created for visitors than with the objects featured in its displays. Visitors' encounter with and movement through the museum is designed to generate discomfort in the darkened, confining corridors; it is the architecture and the arrangement of space itself that prompt 'the demanding emotional experiences the museum affords and the sense of unease it engenders'. ${ }^{51}$ Because the museum resists clarity in favour of ambiguity, it requires visitors to relate to the past affectively, thereby potentially relating to victims of apartheid on a more personal basis. Darren Newbury locates a similar function in the museum's use of photographs from the apartheid era 'to serve as a witness to events, and to impact on the conscience of those who saw the images'. ${ }^{52}$ Museum visitors have a virtual experience created for them in the form of photographs reconstructing key events and sights, and the museum design itself directing their movement, comfort, and encounters as they progress through the space. The museum performs the dual function of archiving individual experiences under apartheid and facilitating new and diverse experiences in reaction to that documentation.

\section{Re-interpreting Historical Narratives}

Multiplicative commemoration also rejects the monologic tendency to extol great men through a re-interpretation of historical narratives that privileges solidarity over hierarchy. Commemorative efforts thus become a site where key democratic values such as inclusion can be exercised, as we see in the example of Robben Island. Billed as 'a symbol of the triumph of the human spirit over adversity', the designated United Nations Educational, Scientific and Cultural Organisation (UNESCO) World Heritage Site of Robben Island seeks to educate public audiences by preserving the structures in which political prisoners were incarcerated in order to stifle popular resistance to apartheid rule. ${ }^{53}$ Though the island operated as a prison and quarantine long before apartheid rule, Robben Island is perhaps best known for housing the maximum-security prison where Nelson Mandela and Walter Sisulu, among others, were held. The Robben Island museum was designed with both political and economic improvement in mind: pragmatically, the site seeks to increase South Africa's international tourism, and politically, the museum contributes to

49 C. Teeger and V. Vinitzky-Seroussi, 'Controlling for Consensus: Commemorating Apartheid in South Africa', Symbolic Interaction, 30, 1 (2007), p. 60; D. Newbury, "Lest We Forget": Photography and the Presentation of History at the Apartheid Museum, Gold Reef City, and the Hector Pieterson Museum, Soweto', Visual Communication, 4, 3 (2005).

50 E. Rankin and L. Schmidt, 'The Apartheid Museum: Performing a Spatial Dialectics', Journal of Visual Culture, 8, 1 (2009), p. 96.

51 Ibid.

52 Newbury, “"Lest We Forget”, p. 267.

53 Robben Island Museum website front page, see http://www.robben-island.org.za/, retrieved 19 October 2016. 
the development of ethical communities and forms of rule that avoid the problems of its national past. $^{54}$

A key feature of the museum is its Memories Project, which archives the recollections of former prisoners and residents. ${ }^{55}$ Compiling and preserving the diverse range of experiences and testimonies demonstrates the museum's commitment to creating solidarity in spite of difference. These individual experiences are granted the spotlight in numerous spaces that extend beyond the museum's exhibits; for example, former detainees conduct the tours of the prison in order to convey personally their first-hand knowledge of the site alongside its general history. ${ }^{56}$ As LiPuma and Koelble note, this approach mirrors a broader post-apartheid agenda 'to acknowledge the creation of solidarity as a way of reconciling the divisiveness of the immediate past as part of a larger project of creating an immanent unity'. 57 This strategy of validating multiple, conflicting voices as a remedy to former exclusions appears frequently in public memory projects like conflict museums that seek to prevent violence by exposing past atrocities. Multiplicative commemoration supports the rainbow nation ethos by reinforcing 'a new founding history in which memory sites such as Robben Island and the Apartheid Museum are central with a core narrative of suffering, struggle and ultimately redemptive unity'. ${ }^{58}$ As such, Robben Island exhibits the second defining characteristic of the multiplicative strategy to commemoration because it invites the re-interpretation and reconstitution of historical narratives to serve the normative expectations of the newly democratic society.

\section{Legitimating Previously Marginalised Voices}

Where the monologic model legitimates white rule, multiplicative commemoration works to restore the status and dignity of those who were marginalised or silenced under previous regimes. Pretoria's Monument to the Women of South Africa, for example, was designed to combat the relative silence about women's contribution to the resistance movement, and thus it pursues a central objective of multiplicative commemoration: that of combating the previous marginalisation of certain groups by amplifying voices typically ignored or repressed. The monument commemorates the 1956 women's march, in which over 20,000 women joined together to challenge proposed amendments to the Urban Areas Act. The multiracial group of women protesters marched to Pretoria and assembled at the steps of the Union Buildings to rally against the injustices of apartheid, and, in doing so, they participated in one of the most visible and influential women's efforts in the fight for freedom. Commissioned in 1998, the monument represents 'the first national effort to recognize women's role in the struggle within the public sphere', and hence was valued not only as a contribution to the multiplicative commemoration of the anti-apartheid struggle but also as a corrective to gender inequalities extending well beyond the apartheid era. ${ }^{59}$

54 S. Nanda, 'South African Museums and the Creation of a New National Identity', American Anthropologist, 106, 2 (2004), pp. 379-85.

55 G.H. Fredericks and C.J. Van Wyk, 'Using Memory as a Tool to Build Museum Collections with Special

Reference to the UWS-Robben Island Mayibuye Archives: The Robben Island Memories Project', Mousaion, 24,2 (2006), pp. 269-82.

56 'The Tour Experience', Robben Island Museum.

57 E. LiPuma and T.A. Koelble, 'Rituals of Solidarity in the New South Africa', Studies in Ethnicity and Nationalism, 11, 1 (2011), p. 5.

58 B. Hamber, 'Conflict Museums, Nostalgia, and Dreaming of Never Again', Peace and Conflict: Journal of Peace Psychology, 18, 3 (2012), p. 277.

59 K. Miller, 'Selective Silence and the Shaping of Memory in Post-Apartheid Visual Culture: The Case of the Monument to the Women of South Africa', South African Historical Journal, 63, 2 (2011), p. 297. 
The monument's symbolic ambiguity invites consideration of the variety characterising groups' experiences of and reasons for opposing apartheid. The sculptural element featured at the centre of the monument is an actual imbokodo, or stone implement used to grind maize in rural areas. The utilisation of this found object to symbolise women's experience of apartheid implicates how 'the economic and political challenges faced by women frequently differ from those faced by men, and ... [how] there may be gendered issues that compel women to activism'. ${ }^{60}$ Given the repeated insistence on inclusivity and equality as guiding principles in the post-apartheid South African nation, the relative paucity of women's monuments seems suspect, but the Monument to the Women of South Africa represents an initial commitment to celebrating women's experiences as one important, previously silenced component of public commemoration of the struggle against apartheid. ${ }^{61}$

\section{Implications of the Multiplicative Model}

Post-apartheid commemoration adhering to the multiplicative model thus publicises viewpoints, experiences, and memories traditionally excluded from public discourse during - and, in some cases, after - apartheid. As we have seen from the examples discussed above, multiplicative commemoration involves a defining focus on individual perspectives and reactions, a (re)construction of historical narratives, and a recuperation of marginalised voices. Multiplicative commemoration thus resists doxastic commemoration in favour of a commitment not to force divergent views and dissenting opinions to dissolve into univocal national consensus.

Controversial sites like the Voortrekker monument and Robben Island hold different significance and implications for different communities within the South African nation, and their interpretation and uptake by these communities for political purposes often clash as their competing narratives vie for dominance in the public sphere. ${ }^{62}$ In some ways, this seems to be the design of the multiplicative approach; to have many points of view counter each other through their co-presence in public spaces.

As Zayd Minty reminds us,

[b]ecause of apartheid and colonialism, heritage is a highly contested and political terrain in South Africa and so it is not surprising that many of these projects question or contest simple narratives of nationalbuilding, teasing out the complexities inherent in a complex and now rapidly changing country. ${ }^{63}$

Minty identifies the importance of such memory work as a component of symbolic reparations, a politically therapeutic counterpart to the land and financial reparations deliberated during the Truth and Reconciliation Commission.

The cacophony of commemorative initiatives in post-1994 South Africa strikes some as a sign that the country "has been in the grip of a "memory boom", ${ }^{64}$ This frenzied rush to fill available public spaces with new and diverse memorial rhetorics constitutes a multiplicative strategy for commemoration because it encourages citizens and political leaders alike to seek the multiplication of perspectives included in the public arena without necessarily accommodating interaction between representations. In simpler terms, this multiplicative commemoration

60 Ibid., p. 301.

61 S. Marschall, 'How to Honour a Woman: Gendered Memorialisation in Post-Apartheid South Africa', Critical Arts, 24, 2 (2010), pp. 260-83.

62 Coombes, History After Apartheid.

63 Z. Minty, 'Post-Apartheid Public Art in Cape Town: Symbolic Reparations and Public Space', Urban Studies, 43, 2 (2006), p. 422.

64 Hlongwane, 'Commemoration, Memory and Monuments', p. 135. 
encourages radical inclusion without also mandating dialogue across difference. Rankin explains this trade-off in terms of the exceedingly difficult task of negotiating the competing objectives of legitimating the past suffering of victims at the same time as memorials and museums avoid producing new forms of exclusion and marginalisation - an understandably difficult balance to strike. $^{65}$

Most important in the context of \#RhodesMustFall, the post-apartheid government pursued multiplicative commemoration because it allowed them to reject the monologic form without also calling for the removal of the products of monologic commemoration - namely, the statues of colonial and apartheid rulers. Erasing these symbols of white rule from the public landscape might appear to promote a new monologism, violating the rainbow nation sensibility. Instead, the multiplicative approach was introduced as a corrective to both the rejected monologic form (by replacing it) and the remaining monologic artefacts (by installing new memorials in the same spaces). However, the \#RhodesMustFall protesters contest this policy's implicit claim that shared space automatically promotes dialogue or that multiple memorials introduce narrative complexity to monologic artefacts. At first glance, the \#RhodesMustFall protesters seem to invert the initial transition strategy by calling for the removal of monologic products (the Rhodes statue). However, we contend that the students' critique primarily engages the multiplicative form of commemoration, suggesting that despite all intentions to increase diversity and inclusion, the multiplicative approach has failed to neutralise the harm of monologic content.

\section{\#RhodesMustFall}

On 9 April 2015, the Rhodes statue was removed by a crew of contractors and a crane from a symbolically and ceremonially important location on the UCT campus. The statue, which had been erected in 1934 to honour Rhodes's contribution of the tract of land that forms a major part of the UCT campus, was the site and subject of a month-long wave of protest. ${ }^{66}$ One month before, a student of politics, Chumani Maxwele, engaged in an act of performative vandalism aimed at the statue on behalf of 'the collective pain and suffering of all black people, particularly protesting the colonial dominance still palpable at UCT' ${ }^{67}$ Maxwele, in a speech that accompanied his performance, asked of his audience, '[t]here is no collective history here where are our heroes and ancestors?' ${ }^{68}$ The following day, the Students' Representative Council endorsed Maxwele's call for the statue's removal in a statement that questioned the validity of memorialising Rhodes at all, and calling for a general meeting to protest against the persistence of the statue on campus. ${ }^{69}$ The quickly adopted \#RhodesMustFall hash-tag encapsulated both the basic mission of the movement and a variety of calls for the transformation of the university environment, symbolically and materially. ${ }^{70}$

65 E. Rankin, 'Creating/Curating Cultural Capital: Monuments and Museums for Post-Apartheid South Africa', Humanities, 2 , 1 (2013), pp. 72-98. See also K.A. Bakker and L. Müller, 'Intangible Heritage and Community Identity in Post-Apartheid South Africa', Museum International, 62, 1-2 (2010), pp. 48-56.

66 BBC, 'Rhodes Statue Removed in Cape Town as Crowd Celebrates', BBC News, available at http://www.bbc.com/news/world-africa-32236922, retrieved 7 May 2015.

67 A. Verbaan, 'UCT Student in Poo Protest - Cape Times', Independent Online, 10 March 2015, available at http://www.iol.co.za/capetimes/uct-student-in-poo-protest-1.1829512\#.VUuSedNViko, retrieved 19 October 2016. 68 Ibid.

69 'Rhodes Falls', Monday Monthly, 34, 3, University of Cape Town, 13 April 2015.

70 The use of social media suffused the protests, influencing both their visual and organisational forms, and making them easy to co-ordinate, publicise, and disseminate to local, national, and international audiences. In this way, \#RhodesMustFall joins a global protest trend designing protest action within the rhetorical conventions of social 
On 17 March, the Executive Committee of the Academics Union put out a statement of support of the emerging protests, saying that the university urgently needed to have 'campuswide discussions ... to set out a clear roadmap for the process of transforming the physical environment of the university including the symbolism of objects and the names of buildings. We need a serious engagement about "heritage that hurts", 71 This heritage, it was implied in the statement, was pent up in the continuities of the memorial landscape on campus. The heritage itself continued to 'hurt' even though there were on campus a number of newer monuments aimed at representing anti-apartheid struggles and Khoisan and Xhosa cultures. The multiplicative model, then, did not alleviate the pain caused by the other monuments. The fact that the colonial and apartheid monuments remained was sufficient proof that the artefacts of the monologic model had resisted meaningful transformation as promised by the multiplicative form.

A group of black faculty called Transform UCT released a statement on 24 March, noting the unreconstructed, monologic power of Rhodes' image on campus:

[t]he state, other symbols on campus, and the general response to this movement speak to the racist and violent history of Rhodes, his image, and our institution. Anger, protest and resistance are appropriate responses to this racist history. To frame the anger of black students as inappropriate is to dismiss and deflect from the deep structural injustices that continue at this institution, which 'reasoned debate' to the extent that it has happened, has not successfully addressed. ${ }^{72}$

Rhodes is a controversial enough figure for the protests against his image to have culminated in and been demobilised by the removal of his statue in April 2015. However, the dissemination of the protests and the sustained mobilisation of the student protesters indicate the salience of the objections to the unfulfilled promises of the negotiated transition from apartheid.

Throughout the protest cycle at UCT, the demands about the physical object of the Rhodes statue were relatively stable. Shortly after the initial protest by Maxwele, there was widespread support among students and faculty leaders for the removal of the statue. What also emerged rather quickly was a widespread attribution of tremendous symbolic weight to this physical object, and the importance of its persistence on campus. The phrase 'heritage that hurts' was used often in discussions about the Rhodes statue in order to convey the ways in which the persistence of this monument on campus was a psychological and emotional burden on students and staff. These troubles were not ameliorated by the inclusion of other perspectives in the monumental architecture on campus. Demands for the inclusion of black students at UCT, including those for 'decolonising' the university, were stymied by the continued presence of the Rhodes statue on the campus. The iconoclasm of the \#RhodesMustFall movement points to ways in which the multiplicative strategy failed to encompass the emergent demands of many for a substantially different and more inclusive kind of recognition.

media use. For similar cases, see Y. Theocharis, W. Lowe, J.W. van Deth, and G. García-Albacete, 'Using Twitter to Mobilize Protest Action: Online Mobilization Patterns and Action Repertoires in the Occupy Wall Street, Indignados, and Aganaktismenoi Movements', Information, Communication and Society, 18, 2 (2015), pp. 202-20; G. Piechota and R. Rajczyk, 'The Role of Social Media during Protests on Maidan', Communication Today, 6, 2 (2015), pp. 87-97; N. Egbunike and A. Olorunnisola, 'Social Media and the \#Occupy Nigeria Protests: Igniting or Damping a Harmattan Storm?', Journal of African Media Studies, 7, 2 (2015), pp. 141-64.

71 'Rhodes Falls'. We argue that the re-naming of campus buildings - for example, Bremner Building to Azania House - during the student occupation of the building, lasting from 20 March to 13 April, does not propose an alternative commemoration. Because the new names given to the buildings do not accord with the aspirations of the monologic model, they do not support a new kind of post-apartheid monologism.

72 Ibid. 
By demanding not just increased representation but the removal of earlier memorialisations, these protests directly confront the multiplicative logic of the transitional period. South African academic Ashwin Desai characterised the critiques offered by \#RhodesMustFall as primarily concerning the transitional period in general, and the figure of Nelson Mandela in particular, who 'rescued' Rhodes through lending his image to the scholarship programme already named for the colonial icon. Desai said of the protests that

a rejection of Rhodes is a rejection of the negotiated settlement that gave rise to the Truth and Reconciliation Commission (TRC) ... Mandela et al, in their zeal to win over the white minority, allowed entities like De Beers, the manifestation of Rhodes's legacy, not to come to the TRC and account. ${ }^{73}$

The protesters, in their own words and actions, call for a new phase of South African recognition that moves beyond the old terminology. They demand recognition based on not a 'reconciled' but a 'transformed' memorial - and, by extension, material - landscape. ${ }^{74}$ This critique aims at the insufficiency of the strategy of multiplication in creating inclusive communities through changing the commemorative landscape. The shift they propose has been described as a demand for a 'second transition' by public figures like Ferial Haffajee ${ }^{75}$ and Max du Preez. ${ }^{76}$

These demands were also articulated around the country, and beyond university campuses. Other protests against apartheid and colonial imagery were undertaken on other university campuses, such as the University of KwaZulu-Natal, Howard College campus, where a statue of King George V was covered in protest signs and paint. ${ }^{77}$ Statues of Gandhi, Queen Victoria, various figures from the Anglo-Boer War, missionaries, and leaders of Boer Republics were splashed with paint, set on fire or spray-painted with slogans in the cities of Pretoria, Port Elizabeth, Cape Town, Durban, Ficksburg, Wellington, Uitenhage, and Johannesburg. ${ }^{78}$ Counterprotesters also came out, some chaining themselves to statues in symbolic protection against defacement, and made claims that the removal of statues was equivalent to a kind of cultural genocide. $^{79}$

73 K. Sosibo, '\#RhodesMustFall Protest Spreads to Other Campuses', Mail and Guardian, 26 March 2015, available at http://mg.co.za/article/2015-03-26-rhodesmustfall-protest-spreads-to-other-campuses, retrieved 19 October 2016.

74 See, for example, K. Sosibo and V. John, 'Leaders of the \#Rhodes rebellion', Mail and Guardian, 2 April 2015, available at http://mg.co.za/article/2015-04-02-leaders-of-the-rhodes-rebellion, retrieved 19 October 2016.

75 F. Haffajee, 'What If There Were No Whites in SA?' IOL Online, 27 November 2015, available at http://www.iol.co.za/dailynews/opinion/what-if-there-were-no-whites-in-sa-1.1951574, retrieved 19 October 2016. 76 BBC, 'Why South Africa's Born-Free Generation Is Not Happy', BBC News, 26 October 2015, available at http://www.bbc.com/news/world-africa-34570761, retrieved 19 October 2016.

77 S. Bhengu, 'Photos: UKZN's King George V Statue Defaced', East Coast Radio, 26 March 2015, available at http://www.ecr.co.za/post/photos-ukzns-king-george-statue-defaced/

78 L. Chutel, 'From Monarchs to Gandhi, South African Statues Vandalized', Associated Press, 14 April 2015, available at

http://www.bostonherald.com/news_opinion/international/africa/2015/04/from_monarchs_to_gandhi_south_african _statues_vandalized, retrieved 19 October 2016; D. Spies, 'War Memorial Statue in Uitenhage "Necklaced"”, News24, 2 April 2015, available at http://www.news24.com/SouthAfrica/News/War-memorial-statue-in-Uitenhageset-alight-20150402, retrieved 19 October 2016.

79 'Protesters to Chain Themselves to Paul Kruger Statue to Defend It', City Press, 7 April 2015, available at http://www.news24.com/Archives/City-Press/Protesters-to-chain-themselves-to-Paul-Kruger-statue-to-defend-it20150430, retrieved 19 October 2016; SABC, 'Protests in Pretoria and Cape Town over Vandalism of Statues', SABC News, 8 April 2015, available at 
The confrontation over these statues is dramatic, but also indicative of underlying conflict over the representativeness of the symbolic landscape after the process of multiplication, and the ways in which the negotiated transition from apartheid to democracy is made concrete. Because the negotiated transition did not always allow for directly iconoclastic movements, the choice to pursue a multiplicative strategy was a way to make space representative and possibly allow for the destabilising of the meanings and importance of older monuments. ${ }^{80}$ However, given the diffusion of the \#RhodesMustFall protests, it seems as if this strategy of inclusion has proven insufficient for many. The enduring question is how simultaneously to remember the trauma of the apartheid and colonial eras, achieve a kind of resolution in the democratic space, and allow for critical memory and discussion of the past.

\section{Conclusion}

The protests associated with the removal of the Rhodes statue from the campus of UCT, in concert with similarly inspired protests around South Africa, seem to point to a new set of demands made largely by a generation whose lives have been shaped in the post-apartheid era. As we have seen, the critique present in such protests is one that is aimed not only at the colonial and apartheid governments, but also at the strategies of the transition from apartheid to multiracial democracy. The students' demands at UCT largely concern what they see as the insufficiency of the change associated with the transition. The persistence of the Rhodes statue in the central part of campus represented a whole host of symbolic continuities that were left relatively intact long after the people and institutions of minority government had fallen.

To be clear, we do not consider the seemingly iconoclastic impulses behind the \#RhodesMustFall movement as analogous to the monumentalising efforts of the colonial, apartheid, and post-apartheid states. Rather we contend that the \#RhodesMustFall protests are a kind of provocation, aimed directly at the multiplicative model of memorialisation that characterised the South African transition to multiracial democracy, and a protest against the monologic artefacts produced by the commemorative approaches of the apartheid and colonial governments. By calling for the removal of a monument, the students and faculty involved in the protest are calling into question the efficacy of the multiplicative model in creating what, in their words, is the 'meaningful transformation' of newly integrated spaces. By rejecting the multiplicative strategy in calling for the removal of a statue, these protesters are simultaneously critiquing and in many ways rejecting the memorialisation strategies of the transitional period. It remains an open question as to whether these calls for removals signal a new, hegemonic monologism, or will inspire the kinds of challenges, conversations and confrontations that, we argue, are so lacking in the multiplicative strategies of the transitional period.

Ultimately, we suggest that the value in understanding \#RhodesMustFall as a critique of the multiplicative strategies lies in identifying a newly emergent site of criticism of the democratic transition by those whose lives have been defined by living under the democratic regime. This critique has been foreshadowed in the literature pointing to the deficiencies of multiplication where meaningful confrontation or conversation does not occur, and it is a strident and challenging one for the post-apartheid state. If multiplication, or indeed a strategy of symbolic reconciliation, has failed to produce a kind of environment upcoming generations feel

http:/www.sabc.co.za/news/a/ab61970047f012f0bc56ff4405f77b26/Protests-in-Pretoria-and-Cape-Town-overvandalism-of-statues-20150408, retrieved 19 October 2016.

80 J. Peffer, 'Censorship and Iconoclasm', in Art and the End of Apartheid (Minneapolis, University of Minnesota Press, 2009), pp. 219-40. 
is sufficiently changed, then the calls for the removal of a statue allude to a much bigger kind of confrontation. For students at UCT, the persistence of Rhodes on campus, even if in the same space as other monuments that seem to challenge his dominance, proves that the campus itself is still colonised. Hence they engage in protests that give voice to their opposition of multiplicative commemoration and the democratic transition, writ large.

Their rejection of the multiplicative transitional strategy represents a provocation to rethink both the shortcomings and the very intention of multiplication in the South African context, and potentially beyond. ${ }^{81}$ \#RhodesMustFall provides one striking indication of a new era of public and monumental culture in South Africa. These protests are distinctly generational, not only because they are largely sparked and undertaken by the so-called 'born frees', but also because they seem to demand something from public spaces that is post-transitional. The shift in language from transition to transformation mirrors this change in emphasis as well. While calling for the removal of a bronze statue, they also call into question the previously unassailable 'miracle' of South Africa's transition from apartheid to multiracial democracy. Although embedded within larger calls for material change, this line of questioning signals a dramatic shift in the articulation of demands for a new kind of (commemorative) public culture in South Africa - one that begins to be not only post-apartheid, but post-transitional as well.

\section{CAROLYN E. Holmes}

Visiting Assistant Professor, Political Science Department, Bucknell University, 701 Moore Ave, Lewisburg, Pennsylvania, PA 17837,USA.E-mail: carolyneholmes@gmail.com

MELANIE LoEHWING

Assistant Professor, Communication Department, Mississippi State University, 75 B.S. Hood Drive, Mississippi, MS 39762,USA.E-mail:mloehwing@comm.msstate.edu

81 In June 2015, calls for the removal of commemorations arose at Oxford University under the banner of \#RhodesMustFallInOxford, using similar terminology (such as calls for 'decolonising' the university), social media approaches, and mobilisation strategies to their South African counterparts. This development, while not the focus of this article, is powerful proof of the salience of the campaign and the calls for change on university campuses. However, we argue that the different settings in which such calls have emerged are reacting to different local contexts. The critique of the images of Rhodes in Oxford, although structurally similar, is not necessarily a critique of the South African transitional strategies, but rather of a monumental stasis on their own campuses, which is the result of different historical trajectories. 